\title{
Remarkable specialization in Eastern Pacific sea fan ectoparasites (Neosimnia)
}
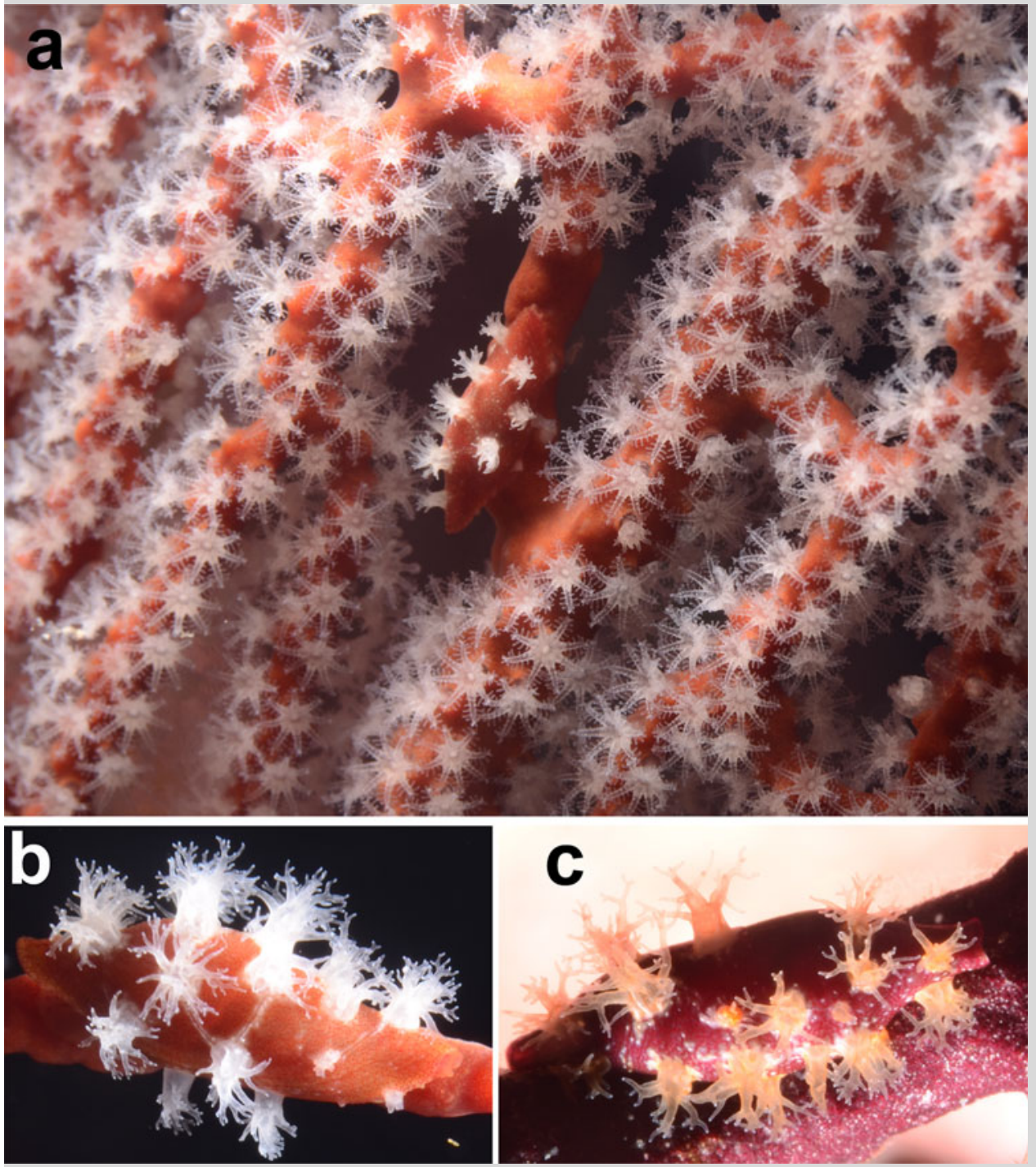

Fig. 1 Images of Neosimnia avena (Mollusca: Gastropoda: Ovulidae) ectoparasites of Eastern Pacific sea fans (Pacifigorgia: Gorgoniidae: Octocorallia) at Malpelo island reefs (Colombia). a Pacifigorgia cf. cairnsi Breedy and Guzmán, 2003 colony with $N$. avena in the center (15 m deep); b, $\mathbf{c} N$. avena with mimic octocoral polyps on the mantle: $\mathbf{b} N$. avena associated with $P$. cf. cairnsi; $\mathbf{c} N$. avena associated with Pacifigorgia cf. curta Breedy and Guzmán, 2003 (orange polyps morphotype, $7 \mathrm{~m}$ deep) (all shells $<15 \mathrm{~mm}$ long)

\section{References}

Lorenz F, Fehse D (2009) The living Ovulidae: a manual of the families of allied cowries: Ovulidae, Pediculariidae and Eocypraeidae. ConchBooks, Hackenheim, p650

Sánchez JA, Gómez CE, Escobar D, Dueñas LF (2011) Diversidad, abundancia y amenazas de los octocorales de la isla Malpelo, Pacífico Oriental Tropical, Colombia. Bol Invest Mar Cost 40:139-154

\section{J. A. Sánchez (囚)}

Laboratorio de Biología Molecular Marina (BIOMMAR), Departamento de Ciencias Biológicas, Facultad de Ciencias, Universidad de los Andes, Bogotá, Colombia

e-mail: juansanc@uniandes.edu.co

Received: 24 December 2012/Accepted: 1 June 2013/Published online: 14 June 2013

Coral Reefs (2013) 32:891

(C) Springer-Verlag Berlin Heidelberg 2013
Ovulids, cowry-like mollusks, are permanent ectoparasites of black corals and octocorals (Lorenz and Fehse 2009). Pacific sea fans (Octocorallia: Gorgoniidae: Pacifigorgia) host an ovulid identified as Neosimnia avena (G. B. Sowerby II, 1832) (Mollusca: Gastropoda: Ovulidae), which mimics its octocoral host matching both coenenchyme and polyps (Fig. 1a-c). There are more than 30 species of Pacifigorgia that are confined to the Eastern Pacific rocky-coral reefs, $N$. avena. At the remote island of Malpelo (Colombia), for instance, there are only two sea fan species with very different colorations and branching shapes (Sánchez et al. 2011), each containing mimetic $N$. avena ectoparasites (Fig. 1b, c). Are all these nearly perfectly adapted symbionts the same species? Is host morphological resemblance a selective driving force for Neosimnia? Although $N$. avena is commonly found on gorgonian corals (Lorenz and Fehse 2009), it is uncertain whether speciation in these symbionts matches the hosts' evolutionary processes. However, Pacifigorgia-N. avena is a promising biological model for studying ecological speciation and coevolution in coral reefs.

Acknowledgments Support from Fundación Malpelo, National Geographic Society-Waitt grants, Smithsonian Tropical Research Institution (STRI), and COLCIENCIAS (grant No. 1204-521tance from Fabio Casas, Carlos Edwin Gómez, Nestor Ardila, Angela FuentesPardo, Luisa F. Dueñas, Sandra Bessudo, Alvaro Buenaventura, Odalisca Breedy, Héctor Guzmán, German Soler, Stan Teillaud, and three anonymous reviewers are greatly appreciated. and each species contains a specialized 29002), as well as comments and assis- 